\title{
APPRAISAL OF SECURITY VIGILANTE AND INFORMANTS IN CRIME CONTROL IN ISIALA MBANO LOCAL GOVERNMENT AREA OF IMO STATE, NIGERIA
}

\author{
Onyeije, Onyinyechi Doris \\ Department of Sociology \\ Imo University, Owerri, Imo State, Nigeria
}

\author{
Okechukwu Anyaoha \\ Department of Sociology, \\ Imo State Uiversity, Owerri, Imo State, Nigeria
}

\author{
Uchenna Iwu \\ Department of Sociology \\ Imo University, Owerri, Imo State, Nigeria
}

\begin{abstract}
The basic trust of this study is to determine the impact of the use of vigilante groups and informants in the control of crime in Isiala Mbano Local Government area of Imo State, Nigeria. This study was descriptive in nature. 749 copies of questionnaire were retrieved from the general public, 15 sets of questionnaire were distributed and retrieved from Rank and File police personnel in each of the three communities selected for the study. Three senior police officers and three Key Informants from each of the communities were interviewed making a total sample of 812 respondents. Data was collected through questionnaire and interview (KIP). Chi-square statistical tool was used to analyze the hypotheses formulated for the study. The findings revealed that vigilante groups are effective in the control of crime and that use of informants by the police did not in any way contribute to crime control. Based on the findings, the study recommended that vigilante groups should be official recognized by the authority and provided with adequate working tools to work, the activities of vigilante groups should be monitored and by the formal police organization to make sure they are not overzealous in the discharge of security duties, the police should develop a water tight method of protecting the identities of informants to encourage more informants in the community, and a good reward system should be established by the communities to encourage the vigilante groups to effectively discharge their duties.
\end{abstract}

Keywords - Community Policing, Crime Reduction, Informants, Crime Reduction, Vigilante Security.

\section{INTRODUCTION}

The Nigeria communities are faced with enormous criminal and antisocial behaviours, which constitute great threat to lives and property in the country, Awurum (2018). The police whose primary function is the protection of lives and property is bedeviled with many challenges, which inhibits the effective discharge of its statutory functions. Issues such as poor salary, shortage of staff, corruption in the system, lack of public cooperation, shortage of working equipment, and more have greatly thwarted the effectiveness of the police in crime reduction and control. The police seem to be the least paid amongst the paramilitary in Nigeria. They seem to work in an un-conducive environment with insufficient and outdated working tools such as gadgets, arms and so on. But in spite of these challenges, effort haves been made by the police to reduce and control crime. These efforts include the use of patrol teams, police informants and vigilante groups etc. However, in all the efforts to checkmate criminal activities, the police seemed to have worked alone as there is still a

gap between the community and the police. In other words, the police may not have collaborated with the community in its effort to reduce and control crime.

The police try to reduce and control crime but their efforts seemed to have proved abortive as crime still persist on a high rate and the gap between the police and the community continue to increase Awurum (2018). This will bring to bear the questioning of whether community policing is necessary in Isiala Mbano Local Government Area of Imo State, Nigeria. There is therefore, need, to examine the effectiveness of community policing, how vigilante security outfit and use of informants have helped in the control of crime in Isiala Mbano L.G.A.

\section{OBJECTIVES OF THE STUDY}

The main objective of this study is to examine whether vigilante security outfit and the use of informants have helped 


\section{International Journal of Engineering Applied Sciences and Technology, 2019 \\ Vol. 4, Issue 5, ISSN No. 2455-2143, Pages 150-157 \\ Published Online September 2019 in IJEAST (http://www.ijeast.com)}

the police in crime control in Isiala Mbano Local Government Area of Imo State, Nigeria.

\section{RESEARCH HYPOTHESES}

To satisfy the objectives of this study the following hypotheses were formulated:

- Vigilante security groups significantly influence crime control

- There is a positive relationship between use of informants and crime control

\section{REVIEW OF LITERATURE AND THEORETICAL FRAMEWORK}

Some scholars have commented on the issue of vigilante groups and crime control. Vigilante is used loosely to refer to a range of different groups, each with different motives. The term has been applied to groups such as Bakassi Boys in Aba, Abia State of Nigeria, who were initially set up with the purpose of fighting crime without an explicit political agenda as well as to others such as Odua People's Congress (OPC), the Yoruba ethnic militia active in the South West of Nigeria. However, from 1999, the OPC changed its fundamental objectives of seeking self-determination for the Yoruba people to crime fighting activities and the settlement of dispute.

The activities of vigilante groups are more visible at night. Zumve (2012) notes that; "generally these groups are more active in the night than during the day.

Usually, able bodied young men of each community supported financially and mentally by other members are charged with the task of securing the community and enforcing law, often with the aid of small weapons, such as machetes, bows and arrows, spears and guns". Ekeh (2019) argues that it does not make sense to talk of government, which is divorced from the protection, it can offer to those under its control. According to him, Nigerian government has virtually told Nigerians to provide for their own protection. It can be deduced from the above that the proliferation of vigilante groups in contemporary Nigeria is as a result of increased crime rate and perhaps practical failure on the part of the police to offer protective services to the people.

Eke (2017), explained that vigilante groups originated due to lack of the presence and laxity of governmental agencies fighting crime in the communities. To this end, the people had no option than to find a way of defending and protecting themselves from criminal victimization. In other words, police in Nigeria seems to be under staffed and cannot cover the nooks and crannies of Nigerian society. In this circumstance, many Nigeria communities have not looked to the Nigeria police force for their protection from violent criminals or from other sources of danger. Instead, they have resorted to other means for their own protection. These means include unregulated and often violent reprisal against suspected sources of their collective endangerment.

The populace for their own protection demanded vigilante groups because the people have no trust in government police organization. As Farris (2018) puts it, "fed up with the soaring crime and ineffective police, Nigerians are embracing vigilante groups despite their murderous methods". In the words of Ali (2016), the Nigerian police are ineffective and corrupt. This fact made the public skeptical about their ability to live up to expectations with respect to crime reduction and control. For Tope (2019), public tolerance of vigilante groups is very high. After suffering years of violent crime, abuse by the security forces, and government inaction, people appeared to have given up expecting the government or the police to provide security or protection. Studies by Sherman (2002 and Kane 2005) revealed that community members' perception of local police and other government institutions in their communities also have colossal influence on community members' decision to volunteer in crime control programmes.

Poor community participation based on lack of trust in the police, however, may be understandable and justifiable because no one would be willing to collaborate with nottrusted partners. A number of other factors may have occasioned the emergence of vigilante groups. Chukwuma (2001) asserts that the inability of the police to protect the lives and property of members of the society has given rise to community efforts at ensuring their own security. Okoro (2019), identified corruption, poverty, brutality, high cost of assessment of police services, non-personal relationship as some of the factors that made people lose faith in the police and their consequent preference for informal policing structures. Nigeria has witnessed the proliferation of private security companies and the surge in informal policing, that is, vigilantism (ethnic and religious) during the last few years. This uprising is attributed to the worrisome state of insecurity in the country in recent times, and the inability of the Nigerian Police Force (NPF) and other related government security agencies to curtail the situation. Thus, through the instrumentality of community policing in Nigeria, neighbourhood watch (vigilantism) has been officially recognized by the police to maintain community safety and security.

Apart from the use of vigilante to curb crime, the use of informant by the police appears to be a laudable technique in crime dictation and solution to some criminal cases. According to Raphael (2016), informants are the people in the community who alert the police concerning criminal activities in their various communities. For him, most community members do not even know these people as police informants. 


\section{International Journal of Engineering Applied Sciences and Technology, 2019 \\ Vol. 4, Issue 5, ISSN No. 2455-2143, Pages 150-157 \\ Published Online September 2019 in IJEAST (http://www.ijeast.com)}

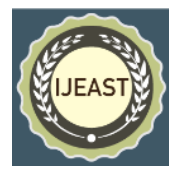

The informants are the most sociable people in the community to the extent that hoodlums and criminals do not suspect their mission in the community. In the view of James (2002), an informant is a person who provides privileged information about a person or organization to an agency. The term is usually used with the law enforcement world, where they are officially known as Confidential or Criminal informants (CI), and can often be used to refer to the supply of information without the consent of the other parties and without the intent of malicious, personal, or financial gain. In the words of Anyaele and Maduekeya (2018), relationship exist between the presence of police informants and crime reduction as the information given to the police by informants serves as a vital tool for the control of crime.

Nwaeze (2010) study on Vigilantism and Crime Control in Contemporary Nigeria in Udenu Local Government Area of Enugu State discovered that, Nigerian police is ineffective with regards to crime control, and vigilante groups in its current form, sprang up to make up for their ineffectiveness. It also found that vigilante groups are gaining prominence as agents of crime control in contemporary Nigeria. A study by Chikwendu, Nwankwo and Oli (2016) on the role of vigilante service groups in crime control for sustainable development in Anambra State, South-East Nigeria found that the informal policing structures are significantly accepted as agents of crime control in communities where they exist.

The Rational Choice theory of James Coleman offers a theoretical explanation to the phenomenon understudy. The basic premise of rational choice theory is that man as an intelligent being considers his actions and choose among alternative the one that best offers maximum satisfaction. For this theory all social behaviours result from individuals who make their own decisions. The theory draws heavily on classical and economic theories of crime. It argues that crimes are broadly the result of rational choices based on the analysis of anticipated costs and benefits (Coleman, 2001). Individuals choose to engage in crime in an effort to maximize their benefits and minimize their lost. Furthermore, it sees the use of vigilante security outfit and informants as a veritable rational choice among alternative to effectively control crime.

\section{Study Area}

Isiala Mbano is located North-East of Imo State capital, Owerri. It is traversed by Owerri, Okigwe, Anara, Umuahia and Okigwe/Umuahia high ways. It is bounded on the north by Onuimo L.G.A. and some parts of Nwangele L.G.A, on the east by Ehime Mbano L.G.A. and on the south by Ikeduru and Mbaitolu L.G.As respectively. It occupies a geographical land mass of 148 sq. Kilometers. It has provisional census figure of 198,736 as at 2006 census. The area was carved out from the former Mbano Local Government Area during the creation of additional local governments in September 1989, with its headquarters situated at Umuelemai, a border town along Anara - Umuahia Federal Road. It is made up of 3 clans namely, Osu, Ugri and Mbama.

The local government is predominantly inhabited by Christians. Isiala Mbano Local Government Area has 28 Autonomous communities. All the autonomous communities have markets, but the major ones that attract or enjoy large patronage include Orie-amaraku, Eke-Anara daily market, Eke-Ezeala, Afor-lbeme, Afor-Amauzari, and Orie-Umuozu among others. Majority of the residents are subsistent farmers while small percentage is engaged in trade. There are successful merchants, industrialists and technocrats in diaspora.

The Local Government Area has palm oil mills located at Umunchi, Umuebie and Umunkwo. There are other small scale industrialists and artisans such as welders, dressmakers, vulcanizers, mechanics, bicycle repairers and more scattered all over the local government area. There are sixty-four primary schools; twenty-six government owned secondary schools and fourteen approved vocational and commercial schools in Isiala Mbano Local Government Area. Currently, there are three commercial bank in Isiala Mbano Local Government Area namely: Sky bank, First bank and Union bank located in Umuelemai, Amaraku and Anara respectively. A standard divisional police station is located at Umuelemai, Amaraku and Anara. The state security service, local vigilante outfits, and other paramilitary groups compliment policing the local government area.

\section{Methodology}

This study was survey in nature and the data for the study was collected through questionnaire and interview of key persons (KIP) such as top police Officers, traditional ruler, and elders of Isiala Mbano. The Yaro Yamane's formula was used to get the sample for the study from three autonomous communities (Umuelemai, Amaraku and Anara) used for the study. These communities have a population of 2862 (NPC, 2006), using Yaro Yamane's formular, a sample of 838 was derived.

The formula for Yaro Yamane is: $\mathrm{n}=\underset{1+\mathrm{N} \times(\mathrm{e})^{2}}{\mathrm{~N}}$

Where

$\mathrm{n}=$ The Sample size

$\mathrm{N}=$ The Population Size

$1=$ The Constant

$\mathrm{e}=$ The Degree of Expected error

The study made use of simple random sampling and a proportionate stratified random sampling to assign each community based on its population strength. Finally, 


\section{International Journal of Engineering Applied Sciences and Technology, 2019 \\ Vol. 4, Issue 5, ISSN No. 2455-2143, Pages 150-157 \\ Published Online September 2019 in IJEAST (http://www.ijeast.com)}

systematic random sampling was used to choose households for the study. Stratified random sampling was used for the three communities not only because it helps to obtain a sample population that best represents the entire population, but also, it was used to ensure the presence of areas with prevalent crime in the sample and ensure the precision of the sample by reducing sampling error. Of 775 set of questionnaire 749 copies of questionnaire were retrieved from the general public, 15 sets of questionnaire were distributed and retrieved from Rank and File police personnel in each of the three communities selected for the study. Three senior police officers and three Key Informants from each of the communities were interviewed making a total sample of 812 respondents. The rank and file police personnel was used for this study because they are the police personnel that are seen in crime hotspots who try to combat crimes and criminal activities, reduce and control crime rate; therefore they have information that aided this research. Chi-Square statistical tool was used to analyze the data and the calculated value of $x^{2}$ was compared to the table value of $x^{2}$ at a significant level of 0.05 at a given degree of freedom.

\section{RESULT AND DISCUSSION}

The table 1 below shows that the males are represented with $36.9 \%$, while the females are represented with $63.1 \%$. The implication of this is that the female folks are more interested when it comes to security issues as they constitute the most vulnerable in Isiala Mbano Local Government Area.

Table -1. Gender distribution of the Respondents

\begin{tabular}{|c|c|c|}
\hline Gender & Frequency & Percentage \\
\hline Male & 300 & 36.9 \\
\hline Female & 512 & 63.1 \\
\hline Total & $\mathbf{8 1 2}$ & $\mathbf{1 0 0}$ \\
\hline
\end{tabular}

Source: Field Survey, 2019.

Table-2. Age of the Respondents

\begin{tabular}{|c|c|c|}
\hline Age & Frequency & Percentage \\
\hline $20-25$ & 118 & 14.5 \\
\hline $26-31$ & 114 & 14.0 \\
\hline $32-37$ & 210 & 25.9 \\
\hline $38-43$ & 214 & 26.4 \\
\hline $44-49$ & 100 & 12.4 \\
\hline $\begin{array}{c}50 \text { and } \\
\text { above }\end{array}$ & 56 & 6.9 \\
\hline & $\mathbf{8 1 2}$ & $\mathbf{1 0 0}$ \\
\hline
\end{tabular}

Source: Field Survey, 2019.

The above table shows that 118 respondents that constitute $14.5 \%$ were in the age bracket $20-25$ years, those within the age bracket $26-31$ and $14 \%$ were 114,210 respondents in the age bracket of $32-37$ were represented with $25.9 \%$. Respondents in the age bracket (38-43), (44-49), and (50 and above) were represented with $26.4 \%, 12.3 \%$, and $6.9 \%$ respectively. The implication of this table is that it shows that those within 38-43 years are more involved and interested in community security issues in Isiala Mbano Local Government Area.

Table - 3. Level of Education of the Respondents

\begin{tabular}{|c|c|c|}
\hline Level of Education & Frequency & Percentage \\
\hline Primary & 37 & 4.5 \\
\hline Secondary & 475 & 58.5 \\
\hline Tertiary & 300 & 37.0 \\
\hline Total & $\mathbf{8 1 2}$ & 100 \\
\hline
\end{tabular}

Source: Field Survey, 2019.

The table above shows that $4.5 \%$ of the respondents attained primary education, $58.5 \%$ attained secondary education, while $37.0 \%$ of the respondents attained tertiary education. This implies that most of the respondents are educated and are aware of the importance a secured community.

Table - 4 Vigilante groups and crime control

\begin{tabular}{|c|c|c|c|c|c|}
\hline Item & Questions & Positive & Negative & Percentage & Total \\
\hline 1 & $\begin{array}{l}\text { Vigilante } \\
\text { groups } \\
\text { exist in } \\
\text { Isiala } \\
\text { Mbano } \\
\text { L.G.A. }\end{array}$ & $\begin{array}{c}780 \\
(96.1 \%)\end{array}$ & $32(3.9 \%)$ & 100 & 812 \\
\hline 2 & $\begin{array}{l}\text { The } \\
\text { presence } \\
\text { of } \\
\text { vigilante } \\
\text { groups } \\
\text { has } \\
\text { helped in } \\
\text { reducing } \\
\text { the rate } \\
\text { of crime } \\
\text { in Isiala } \\
\text { Mbano } \\
\text { L.G.A. }\end{array}$ & $\begin{array}{c}750(92.4 \\
\%)\end{array}$ & $62(7.5 \%)$ & 100 & 812 \\
\hline 3 & $\begin{array}{l}\text { Vigilante } \\
\text { groups } \\
\text { are very } \\
\text { effective } \\
\text { in } \\
\text { combatin } \\
\text { g crime } \\
\text { in Isiala } \\
\text { Mbano } \\
\text { L.G.A }\end{array}$ & $\begin{array}{c}780 \\
(96.1 \%)\end{array}$ & $32(3.9 \%)$ & 100 & 812 \\
\hline 4 & $\begin{array}{l}\text { The } \\
\text { presence } \\
\text { of } \\
\text { vigilante } \\
\text { groups } \\
\text { has not } \\
\text { contribut } \\
\text { ed to } \\
\text { crime } \\
\text { reduction } \\
\text { and } \\
\text { control in }\end{array}$ & $2(0.2 \%)$ & $\begin{array}{c}810 \\
(99.8 \%)\end{array}$ & 100 & 812 \\
\hline
\end{tabular}




\begin{tabular}{|l|l|l|l|l|l|}
\hline & $\begin{array}{l}\text { Isiala } \\
\text { Mbano } \\
\text { L.G.A. }\end{array}$ & & & & \\
\hline
\end{tabular}

Source: Field Survey, 2019

The table above shows that $91.1 \%$ of the respondents responded positively to the question in item one, $3.9 \%$ responded negatively. $92.4 \%$ responded positively to the question in item two, while $7.6 \%$ responded negatively. $96.1 \%$ responded positively to the question in item three, while $3.9 \%$ responded negatively to the question in item three. $0.2 \%$ responded positively to the question in item four, while $99.8 \%$ responded negatively. The implication of this is that majority of the respondents were of the view that vigilante security outfit has helped in the control of crime in Isiala Mbano.

Table- 5. Use of informants and crime control

\begin{tabular}{|c|c|c|c|c|c|}
\hline Item & Questions & Positive & Negative & Percentage & Total \\
\hline 1 & $\begin{array}{l}\text { There are } \\
\text { police } \\
\text { informants } \\
\text { in Isiala } \\
\text { Mbano } \\
\text { L.G.A. }\end{array}$ & $\begin{array}{c}142 \\
(17.5 \%)\end{array}$ & $\begin{array}{c}670 \\
(82.5 \%)\end{array}$ & 100 & 812 \\
\hline 2 & $\begin{array}{l}\text { Police } \\
\text { informants } \\
\text { have } \\
\text { helped in } \\
\text { arresting } \\
\text { criminals } \\
\text { in Isiala } \\
\text { Mbano } \\
\text { L.G.A. }\end{array}$ & $\begin{array}{c}82 \\
(10 \%)\end{array}$ & $730(90 \%)$ & 100 & 812 \\
\hline 3 & $\begin{array}{l}\text { Police } \\
\text { informants } \\
\text { have been } \\
\text { a veritable } \\
\text { instrument } \\
\text { in crime } \\
\text { reduction } \\
\text { and control } \\
\text { in Isiala } \\
\text { Mbano } \\
\text { L.G.A. }\end{array}$ & $\begin{array}{c}212 \\
(26.1 \%)\end{array}$ & $\begin{array}{c}600 \\
(73.9 \%)\end{array}$ & 100 & 812 \\
\hline 4 & $\begin{array}{l}\text { Police } \\
\text { informants } \\
\text { have not } \\
\text { been } \\
\text { helpful in } \\
\text { combating } \\
\text { crime in } \\
\text { Isiala } \\
\text { Mbano } \\
\text { L.G.A. }\end{array}$ & $\begin{array}{c}612 \\
(75 \%)\end{array}$ & $200(25 \%)$ & 100 & 812 \\
\hline
\end{tabular}

Source: Field Survey, 2019.

The table above shows that $17.5 \%$ responded positively, while $82.5 \%$ responded negatively to the question in item one. $10 \%$ responded positively to the question in item two, while $90 \%$ responded negatively to the same question in the same item.
$26.1 \%$ and $73.9 \%$ responded positively and negatively to the question in item three respectively. $75 \%$ responded positively to the question in item four while $25 \%$ responded negatively. This shows that majority of the people were of the view that use of informants has not been effective in control of crime in Isiala Mbano. This is not unconnected to the fact the people mistrust and the negative attitude the people have about the police.

\section{Testing of Hypotheses}

\section{Hypothesis One}

- H1 Vigilante security groups significantly influence crime control

- Ho Vigilante security groups do not significantly influence crime control

Table - 6 Chi-square analysis for vigilante outfit and crime control

\begin{tabular}{|c|c|c|c|c|c|}
\hline Item & Questions & Positive & Negative & Percentage & Total \\
\hline 1 & $\begin{array}{l}\text { Vigilante } \\
\text { groups } \\
\text { exist in } \\
\text { Isiala } \\
\text { Mbano } \\
\text { L.G.A. }\end{array}$ & $\begin{array}{c}780 \\
(96.1 \%)\end{array}$ & $32(3.9 \%)$ & 100 & 812 \\
\hline 3 & $\begin{array}{l}\text { Vigilante } \\
\text { groups are } \\
\text { very } \\
\text { effective } \\
\text { in } \\
\text { combating } \\
\text { crime in } \\
\text { Isiala } \\
\text { Mbano } \\
\text { L.G.A }\end{array}$ & $\begin{array}{c}780 \\
(96.1 \%)\end{array}$ & $32(3.9 \%)$ & 100 & 812 \\
\hline
\end{tabular}

Source: Field Survey, 2019.

Computing the Formula for Chi-square

$$
x^{2}=\frac{\sum(\mathrm{O}-\mathrm{E})^{2}}{\mathrm{E}_{1}}
$$

Where

$$
\begin{aligned}
& \begin{array}{l}
\sum=\text { Summation } \\
\mathrm{O}=\text { Observed Frequency }
\end{array} \\
& \mathrm{E}=\text { Expected Frequency }
\end{aligned}
$$

To obtain the expected frequencies

$\mathrm{E}=$ Row total $\times$ column total

Grand total

$$
=600 \times 812 \div 1624=300
$$




\section{International Journal of Engineering Applied Sciences and Technology, 2019 \\ Vol. 4, Issue 5, ISSN No. 2455-2143, Pages 150-157 \\ Published Online September 2019 in IJEAST (http://www.ijeast.com)}

Cell $\mathrm{A}_{1} \mathrm{~B}_{1}$

\begin{tabular}{|c|c|c|c|c|c|}
\hline Cell $\mathrm{A}_{2} \mathrm{~B}_{1}$ & $=$ & $154 \times 812$ & $\div$ & 1624 & $=$ \\
\hline Cell $\mathrm{A}_{3} \mathrm{~B}_{1}$ & $=$ & $610 \times 812$ & $\div$ & 1624 & $=$ \\
\hline Cell $\mathrm{A}_{4} \mathrm{~B}_{1}$ & $=$ & $260 \times 812$ & $\div$ & 1624 & $=$ \\
\hline Cell $A_{1} B_{2}$ & $=$ & $600 \times 812$ & $\div$ & 1624 & $=$ \\
\hline Cell $A_{2} B_{2}$ & $=$ & $154 \times 812$ & $\div$ & 1624 & $=$ \\
\hline Cell $A_{3} B_{2}$ & $=$ & $610 \times 812$ & $\div$ & 1624 & $=$ \\
\hline Cell $\mathrm{A}_{4} \mathrm{~B}_{2}$ & $=$ & $260 \times 812$ & $\div$ & 1624 & $=$ \\
\hline
\end{tabular}

Table - 7. Observed frequency

\begin{tabular}{|c|c|c|c|c|c|}
\hline Cell & O & E & O-E & $(\text { O-E })^{2}$ & $\frac{(\text { O-E })^{2}}{\text { E }}$ \\
& & & & & \\
\hline Cell $A_{1} B_{1}$ & 600 & 300 & 300 & 600 & 2 \\
\hline Cell $A_{2} B_{1}$ & 150 & 77 & 73 & 146 & 1.9 \\
\hline Cell $A_{3} B_{1}$ & 2 & 305 & -303 & -606 & -2 \\
\hline Cell $A_{4} B_{1}$ & 60 & 130 & -70 & -140 & -1.1 \\
\hline Cell $A_{1} B_{2}$ & 0 & 300 & -300 & -600 & -2 \\
\hline Cell $A_{2} B_{2}$ & 4 & 77 & -73 & -146 & -1.9 \\
\hline Cell $A_{3} B_{2}$ & 608 & 305 & 303 & 606 & 2 \\
\hline Cell $A_{4} B_{2}$ & 200 & 130 & 70 & 140 & 1.1 \\
\hline Total & & & & & 14 \\
\hline
\end{tabular}

The above table is a $4 \times 2$ contingency table. The degree of freedom is derived as follows:

The degree of freedom $=\mathrm{df}$ is traced to chi-square table of value

Where:

$$
\begin{aligned}
& \text { df }=(\mathrm{C}-1)(\mathrm{R}-1) \\
& (\mathrm{df})=(4-1)(2-1) \\
& (\mathrm{df})=3 \times 1 \\
& \mathrm{df}=3
\end{aligned}
$$

The table value of $x^{2}$ at a significant level of 0.05 and degree of freedom of $3=7.815$. The calculated value of $x^{2}=14$

\section{Decision Rule}

When the calculated value of $x^{2}$ is greater than the table value, we reject the null (Ho) and accept the alternative (Hi). However, when the calculated value less than the table value, we reject the alternative and accept the null hypothesis.

The calculated value of $x^{2}$ is 14 . While at the significant level of 0.05 and degree of freedom of 3 the table value of $x^{2}$ 7.815 .

Since the table value of $x^{2}$ is less than the calculated value of $x^{2}$, therefore the null hypothesis, which states that vigilante security groups do not significantly influence crime control in Isiala Mbano Local Government Area of Imo state is rejected.

\section{Hypothesis Two}

- H1 There is a positive relationship between police informants and crime control.

- Ho There is no positive relationship between police informants and crime control.

Table - 8. Chi-square analysis use of informant and crime control

\begin{tabular}{|c|l|c|c|c|c|}
\hline Item & Questions & Positive & Negative & Percentage & Total \\
\hline 2 & $\begin{array}{l}\text { Police } \\
\text { informants } \\
\text { have } \\
\text { helped in } \\
\text { arresting } \\
\text { criminals } \\
\text { in Isiala } \\
\text { Mbano }\end{array}$ & $\begin{array}{l}\text { 730 } \\
\text { L.G.A. }\end{array}$ & $\begin{array}{c}\text { 82 } \\
(10 \%)\end{array}$ & $\mathbf{1 0 0}$ & $\mathbf{8 1 2}$ \\
\hline 4 & $\begin{array}{l}\text { Police } \\
\text { informants } \\
\text { have not } \\
\text { been } \\
\text { helpful in } \\
\text { combating } \\
\text { crime in } \\
\text { Isiala } \\
\text { Mbano } \\
\text { L.G.A. }\end{array}$ & $\begin{array}{l}\text { (0.5\%) } \\
(99.5 \%)\end{array}$ & $\mathbf{8 0 8}$ & $\mathbf{8 1 2}$ \\
\hline
\end{tabular}

Source: Field Survey, 2019.

Computing the Formula for Chi-square

$$
x^{2}=\frac{\sum(\mathrm{O}-\mathrm{E})^{2}}{\mathrm{E}_{1}}
$$

Where

$$
\begin{aligned}
& \sum=\text { Summation } \\
& \mathrm{O}=\text { Observed Frequency } \\
& \mathrm{E}=\text { Expected Frequency }
\end{aligned}
$$

To obtain the expected frequencies

$\mathrm{E}=$ Row total $\times$ column total

Grand total 


\section{International Journal of Engineering Applied Sciences and Technology, 2019 \\ Vol. 4, Issue 5, ISSN No. 2455-2143, Pages 150-157 \\ Published Online September 2019 in IJEAST (http://www.ijeast.com)}

\begin{tabular}{|c|c|c|c|c|c|c|}
\hline Cell $A_{1} B_{1}$ & $=$ & $730 \times 812$ & $\div$ & 1624 & $=$ & 365 \\
\hline Cell $\mathrm{A}_{2} \mathrm{~B}_{1}$ & $=$ & $300 \times 812$ & $\div$ & 1624 & $=$ & 150 \\
\hline Cell $A_{3} B_{1}$ & $=$ & $154 \times 812$ & $\div$ & 1624 & $=$ & 77 \\
\hline Cell $\mathrm{A}_{4} \mathrm{~B}_{1}$ & $=$ & $140 \times 812$ & $\div$ & 1624 & $=$ & 70 \\
\hline Cell $A_{1} B_{2}$ & $=$ & $730 \times 812$ & $\div$ & 1624 & $=$ & 365 \\
\hline Cell $\mathrm{A}_{2} \mathrm{~B}_{2}$ & $=$ & $300 \times 812$ & $\div$ & 1624 & $=$ & 150 \\
\hline Cell $\mathrm{A}_{3} \mathrm{~B}_{2}$ & $=$ & $154 \times 812$ & $\div$ & 1624 & $=$ & 77 \\
\hline Cell $\mathrm{A}_{4} \mathrm{~B}_{2}$ & $=$ & $140 \times 812$ & $\div$ & 1624 & $=$ & 70 \\
\hline
\end{tabular}

Table - 9. The observed frequency in a tabular form

\begin{tabular}{|c|c|c|c|c|c|}
\hline Cell & $\mathbf{O}$ & $\mathbf{E}$ & O-E & $(\mathrm{O}-\mathrm{E})^{2}$ & $\frac{(\text { O-E })^{2}}{\mathbf{E}}$ \\
\hline Cell $\mathbf{A}_{1} \mathbf{B}_{1}$ & 630 & 365 & 265 & -130 & 1.5 \\
\hline Cell $A_{2} B_{1}$ & 100 & 150 & -50 & -10 & -1 \\
\hline Cell $\mathbf{A}_{3} \mathbf{B}_{1}$ & 62 & 77 & -15 & 100 & -0.4 \\
\hline Cell $A_{4} B_{1}$ & 20 & 70 & -50 & 240 & -1.4 \\
\hline Cell $A_{1} B_{2}$ & 400 & 365 & 35 & 130 & 0.2 \\
\hline Cell $\mathbf{A}_{2} \mathbf{B}_{2}$ & 200 & 150 & 50 & 10 & 1 \\
\hline Cell $\mathbf{A}_{3} \mathbf{B}_{2}$ & 92 & 77 & 15 & 100 & 0.4 \\
\hline Cell $\mathbf{A}_{4} \mathbf{B}_{2}$ & 120 & 70 & 50 & -240 & 1.4 \\
\hline Total & & & & & 7.3 \\
\hline
\end{tabular}

The above table is a $4 \times 2$ contingency table and the degree of freedom is derived as follows:

Where:

$$
\begin{aligned}
\text { df } & =(\mathrm{C}-1) \\
(\mathrm{df}) & =(4-1) \quad(2-1) \\
(\mathrm{df}) & =3 \times 1 \\
\mathrm{df} & =3
\end{aligned}
$$

The table value of $x^{2}$ at a significant level of 0.05 and degree of freedom of $3=7.815$. The calculated value of $x^{2}=7.3$

\section{Decision Rule}

When the calculated value of $x^{2}$ is greater than the table value, we reject the null (Ho) and accept the alternative (Hi). However, when the calculated value less than the table value, we reject the alternative and accept the null hypothesis.

The calculated value of $x^{2}$ is 7.3. While at the significant level of 0.05 and degree of freedom of 3 the table value of $x^{2}$ 7.815 .

Since the table value of $x^{2}$ is greater than the calculated ve of $x^{2}$, therefore the null hypothesis, which states that there is no significant relationship between use of informant and control in Isiala Mbano L.G.A is accepted.

\section{Discussion of results}

The findings of this study reveal that the presence of vigilante groups in Isiala Mbano have helped in crime control. This is supported by the key important personnel (KIP) interviewed agreed that vigilante groups have been very effective and has helped tremendously to reduce crime in Isiala Mbano Local Government Area of Imo State. This is also in line with the opinion of the majority of the respondents $(780(96.1 \%)$ that presence of vigilante groups has helped in reducing the rate of crime in Isiala Mbano L.G.A...

Furthermore, the study also reveals that the use of informants does not help in crime control in Isiala Mbano. This is in contrast with view of the police interviewed that police cannot get its work done without informants and their information. The opinion of the majority of respondents agree $600(73.9 \%)$ support this finding that Police informants have not been a veritable instrument in crime reduction and control in Isiala Mbano L.G.A. The key important personnel interviewed for this study attributed this to mistrust and fear the people have that the police will reveal their identity to the criminals. The corruption in the police did not help matters as some of these criminals bribe their ways out of detention and seen in the communities, which have sent a dangerous signals to would be informants.

Relationship exists between the presence of vigilante groups and crime control in Isiala Mbano. This is in line with the view of the police personnel interviewed that vigilante groups has been very effective and has helped tremendously to reduce crime in Isiala Mbano Local Government Area of Imo State. It is also in line with the finding of Eke (2017) that vigilante groups have been so effective in combating crime in most Nigerian societies, these groups have proven to some extent that crime control is highly achievable.

Furthermore, we found that there is no significant relationship between police informants and crime control in Isiala Mbano. This is in contrast with view of the police interviewed that police can not get its work done without informants and their information. It is also in contrast with the findings of Anyaele and Maduekeya (2018), that relationship exist between the presence of police informants and crime reduction as the information given to the police by informants serves as a vital tool for the control of crime.

\section{CONCLUSION}

This work aimed at examining the effectiveness of community policing, how vigilante security outfit and use of informants have helped in the control of crime in Isiala Mbano Local Government Area of Imo State Nigeria. . In the course of this study, it was observed that the police is a regimental organization and is on order and directives. Each division has its specific jurisdiction and may not get involved in another jurisdiction therefore, they expect the people to be the police 


\section{International Journal of Engineering Applied Sciences and Technology, 2019 \\ Vol. 4, Issue 5, ISSN No. 2455-2143, Pages 150-157 \\ Published Online September 2019 in IJEAST (http://www.ijeast.com)}

themselves and then give feedback to the police organization. In other words, even when a crime is reported, the police may not act if there is no order or directive from above to do so because the police do not interfere with crime issues outside its specific location.

Nigerian society is faced with enormous security challenges which have made the government to beef up security in the country. It can also be said that crime rate is gradually reducing. The issue of crime in Isiala Mbano is gradually becoming outdated because of the effectiveness of the vigilante groups in the area, which has eventually made the people to develop confidence in them. It was observed that the government has failed to provide for the welfare of the police, which is saddled, with the task of protecting lives and property of the citizenry. The police lack police quarters, arms, good salary scale, battings, touch lights, communication gadgets. It was also observed that the police still use outdated patrol vans and guns and the police are short-staffed.

\section{RECOMMENDATIONS}

Base on the findings of this study, the following recommendation were made:

1. The vigilante groups should be official recognized by the authority and provided with adequate working tools such as touch lights, and other necessary materials to enable them carryout their duties effectively

2. The activities of vigilante groups should be monitored and by the formal police organization to make sure they are not overzealous in the discharge of security duties.

3. The police should develop a water tight method of protecting the identities of informants as this will encourage more informants in the community.

4. A good reward system should be established by the communities to encourage the vigilante groups to effectively discharge their duties.

\section{REFERENCE}

[1] A. Maduekeya, Community Policing under Nigeria's National Security Owerri. Canum Publishers Nig. Ltd, pp. 17, 2018.

[2] A. Ndubuisi, Persistent increase in Crime Rate in Nigerian Communities. Owerri :Cel-Bez Publishing Co. Ltd. pp. 30-33, 2018.

[3] A.Tope The Impact of Emotional Intelligence on Community policing in Democratic Nigeria Agenda Setting for National Development. Global Community Policing Problems and Challenges, CRC press, 25-40, 2019.
[4] C. Stella, N. Ifeoma, N. Oli, The Role of Vigilante Service Groups in Crime Control for Sustainable Development in Anambra State, South-East Nigeria. Greener Journal of Social Sciences, 6(3): 065-074, 2016.

[5] E. Odili, "Political Economy of Community Policing under Nigeria's National Security Dilemma", Journal of International Politics and Development Studies 5 (1) 2, 2019.

[6] E. Patiece, A review of HRW's and CLEEN's report: the legitimization of murder and torture on state sponsored vigilante groups in Nigeria. Retrieved June 21, 2017 from http://www.africaresource.com/content/view/35/68, 2017.

[7] I. Chukwuma, Police Transformation in Nigeria: Problems and prospects. In Crime and Policing in Transitional Societies. Johannesburg: South African Institute of International Affairs. Seminar Report No. 8, 2001.

[8] J. Coleman, The Practice of Principle: In Defense of a Pragmatist Approach to Legal Theory. Oxford: Oxford University Press, 2001.

[9] K. Ali, Informers and the battle against republican terrorism: A review of 30 year of conflict. Police Practice \& Research, 6(2): 165-180, 2016.

[10] L. Sherman, "Fair and effective policing. In Crime: Public policies for crime control", eds. JG Wilson, J Petersilia. Oakland: Institute for Contemporary Studies, 2002.

[11] N. Ignatius, "Vigilantism and Crime Control in Contemporary Nigeria: A study of Udenu Local Government Area of Enugu State". A Thesis Submitted to the Department of Sociology and Anthropology, University of Nigeria, Nsukka. 2010.

[12] National Population Commission, Imo state, Abuja: N.P.C Census 2006

[13] O. Rapheal "An Assessment of Community PolicingOriented Training Programme in Benue and Lagos States, Nigeria”. Social Criminology, 5: 162, 2016.

[14] R. Kane,"Compromised police legitimacy as a predictor of violent crime in structurally disadvantaged communities." Criminology 43 (2): 469-498, 2005.

[15] T. Farris, "Bakassi Boys:The Legitimization of Murder and Torture". Retrieved from http://www.org/report/2002/nigeria2/nigeria0502-02.htm. May 21, 2018. 